\title{
The influence of fasting/refeeding on the lipoprotein lipase activity of adipose tissue and muscle
}

\section{L.M. Botion}

\section{Correspondence}

L.M. Botion

Departamento de Fisiologia e

Biofísica, ICB, UFM G

Av. Antonio Carlos, 6627

31270-901 Belo Horizonte, MG

Brasil

Fax + 55-31-3499-2924

E-mail: botion@ icb.ufmg.br

Research supported by CNPq (No. 520.544/94-9), FAPEMIG (No. 909/95) and Pró-reitoria de Pesquisa e Pós-graduação (PRPq), UFMG.

Received January 16, 2001 Accepted August 16, 2001 Departamento de Fisiologia e Biofísica, Instituto de Ciências Biológicas,
Universidade Federal de Minas Gerais, Belo Horizonte, MG, Brasil

\section{Abstract}

Lipoprotein lipase activity in adipose tissue and muscle is modulated by changes in the pattern of food intake. We have measured total lipoprotein lipase activity in adipose tissue and muscle of male Wistar rats ( $\mathrm{N}=6-10)$, weighing 200-250 g ( 12 weeks), during the refeeding/fasting state following $24 \mathrm{~h}$ of fasting. Lipoprotein lipase activity in tissue homogenates was evaluated using a $\left[{ }^{3} \mathrm{H}\right]$-triolein-containing substrate, and released $\left[{ }^{3} \mathrm{H}\right]$-free fatty acids were extracted and quantified by liquid scintillation. Adipose tissue lipoprotein lipase activity did not completely recover within $2 \mathrm{~h}$ of refeeding (60\% of refed ad libitum values). Cardiac lipoprotein lipase activity remained increased even $2 \mathrm{~h}$ after refeeding (100\% of refed ad libitum values), whereas no significant changes were observed in the soleus and diaphragm muscles. Adipose tissue lipoprotein lipase activities were consistently higher than the highest skeletal muscle or heart values. It is therefore likely that adipose tissue, rather than muscle makes the major contribution to triacylglycerol clearance. There was concomitant relatively high lipoprotein lipase activity in both adipose tissue and cardiac muscle during the first few hours of refeeding, therefore cardiac muscle may contribute significantly to triacylglycerol clearance during this period. The results suggest that during fasting, increased lipoprotein lipase activity provides a complementary source of free fatty acids from circulating triacylglycerol, allowing the heart to maintain its continuous, highenergy expenditure.

Lipoprotein lipase (LPL; EC 3.1.1.34) hydrolyzes the triacylglycerol (TAG) molecules present in circulating lipoproteins to provide free fatty acids (FFA) and monoacylglycerol to be utilized by tissue. LPL is synthesized in the parenchymal cells of extra-hepatic tissues, including adipose tissue, cardiac and skeletal muscle, and is translocated to its physiological site of action in the capillaries, where it binds to heparan sulfate

\section{Key words}

- Cardiac lipoprotein

lipase

- Adipose tissue lipoprotein lipase

- Skeletal muscle

lipoprotein lipase

- Fasting proteoglycan chains on endothelial cells (1). Attached to the endothelium, the enzyme hydrolyzes TAG-rich lipoproteins and this fraction of the enzyme is referred to as the functional fraction and can be released from its binding sites by heparin (2-5). LPL activity can be altered in a tissue-specific manner, which is physiologically important because it directs fatty acid utilization according to the demands of individual tissues, so that the 
degradation of TAG-rich lipoproteins can be targeted to specific sites. The highest activities are found in tissues that oxidize (heart and red skeletal muscle) and esterify (adipose tissue) large quantities of fatty acids (5).

Of the several hormones involved in LPL modulation, insulin has been shown to correlate positively with enzyme activity in adipose tissue and negatively with its activity in skeletal muscle and heart (4). Other studies also have shown that LPL regulation is often opposite in adipose tissue and muscle in response to the same nutritional treatment. Starvation is associated with a decrease in LPL activity in adipose tissue (2-9) and an increase in heart and oxidative skeletal muscle (2-6,8). However, this common reciprocal regulation of LPL may not be a general rule since cardiac muscle LPL activity was shown to be regulated in the same direction as the adipose tissue LPL activity in underfed ewes (10) and was unaffected in starved guinea pigs (11). Although an increase in skeletal muscle LPL activity in starved rats has been generally reported (28 ), a lack of variation has also been described $(4,6,7,10,11)$ depending on experimental conditions, and noticeably for starvation duration (9). The evidence that LPL activity is an important determinant of the ability of tissues to remove TAG from the circulation has been reviewed extensively; however, most of these studies examined adipose and muscle LPL regulation at only one point in time after long-term refeeding or food restriction. Thus, the present study was designed to compare heart, skeletal muscle and adipose tissue LPL activities during short- and long-term fasting/refeeding periods.

Male Wistar rats weighing 200-250 g were sampled in the fed state at the end of the dark phase (ad libitum fed controls, $\mathrm{N}=10$ ), after starvation (fasted $24 \mathrm{~h}, \mathrm{~N}=10$ and fasted $48 \mathrm{~h}, \mathrm{~N}=6$ ), or after starvation for 24 $\mathrm{h}$ followed by the provision of standard chow for $2 \mathrm{~h}$ (in order to synchronize the eating patterns of all animals) and sacrificed $0(\mathrm{~N}=$ 6) or $4 \mathrm{~h}(\mathrm{~N}=6)$ after refeeding (fasted/refed $0 \mathrm{~h}$ or fasted/refed $4 \mathrm{~h}$ ). LPL activity was measured in epididymal adipose tissue and in soleus, diaphragm and heart muscle homogenates (12) using a $\left[{ }^{3} \mathrm{H}\right]$-triolein-containing substrate emulsified with lecithin (13) and containing 24-h fasted rat plasma as a source of apo $\mathrm{C}_{\mathrm{II}}$. The reaction was stopped by the addition of a mixture of chloroformmethanol-heptane (14), and released $\left[{ }^{3} \mathrm{H}\right]$ FFA were separated and quantified by liquid scintillation. Activity was expressed as $\mu \mathrm{mol}$ FFA released $\mathrm{h}^{-1} \mathrm{mg}$ protein ${ }^{-1}$. Protein content of the homogenates was measured by the method of Lowry et al. (15).

The results of the present study confirm and extend earlier observations concerning the effect of fasting/refeeding on LPL activity in muscle and adipose tissue. As can be seen in Figure 1A, LPL activity decreased in rat epididymal adipose tissue following a 24-h fast and extending the starvation period from 24 to $48 \mathrm{~h}$ did not produce any further changes. After rats were refeed for $2 \mathrm{~h}$, their LPL activity increased to $36 \%$ that of starved rats independently of whether the animals were sacrificed immediately or $4 \mathrm{~h}$ after refeeding, suggesting that LPL activity can quickly be increased to handle and store the ingested lipid. However, it was apparent that LPL in epididymal adipose tissue was resistant to complete re-activation within $2 \mathrm{~h}$ of refeeding (Figure 1A). It is likely that alterations in LPL specific activity contribute to the observed effects, since it was demonstrated that LPL degradation is faster in adipocytes of starved rats $(\sim 19 \mathrm{~h})$ compared with fed rats, and the synthesis of the enzyme was unchanged during this time (9). In addition, insulin is thought to be of major importance in eliciting the macronutrientspecific changes in LPL activity in response to food intake and a striking correlation between the pattern of changes in adipose tissue LPL activities and plasma insulin con- 
centrations has been reported $(4,8)$.

The activity of the cardiac enzyme remained significantly higher (similar to fasting values) after $2 \mathrm{~h}$ of refeeding and significant suppression of enzyme activity was elicited only in the continuously ad libitum fed state (Figure 1B). These results raise the possibility that fatty acids derived from dietary TAG (rather than from adipose tissue TAG) are used as oxidative substrates by the heart during this period. Recent evidence suggests that the ability of the heart vascular endothelium to bind LPL changes with fasting (16). These studies showed that the fraction of injected ${ }^{125}$ I-labeled bovine LPL that bound in the heart was higher in fasted than in fed rats in isolated hearts and this was reversed after $5 \mathrm{~h}$ refeeding (16). Another study on perfused hearts showed a dramatic increase in the functional fraction of LPL within $1 \mathrm{~h}$ after fat feeding (17). These studies suggest that during short-term refeeding the functional fraction of cardiac LPL is still active in the capillary endothelium.

Variations in the LPL activities of soleus and diaphragm muscles were not so clear and no significant differences were observed independently of fasting/refeeding state (Figure $1 \mathrm{C}, \mathrm{D})$. One mediator that may be postulated to regulate LPL activity during different nutritional states is insulin $(4,18)$, and it is possible that postprandial fluctuations in insulin concentrations may have to reach some threshold of magnitude to affect muscle LPL activity. This is supported by the fact that ingestion of a high-fat diet, which elicits a smaller insulin increase than a high-carbohydrate diet, was followed by much smaller changes in LPL in the muscle tissues examined (18). Taken together, the results suggest that skeletal muscle LPL is less sensitive to common regulatory factors than cardiac LPL.

Interestingly, the decline in adipose tis-

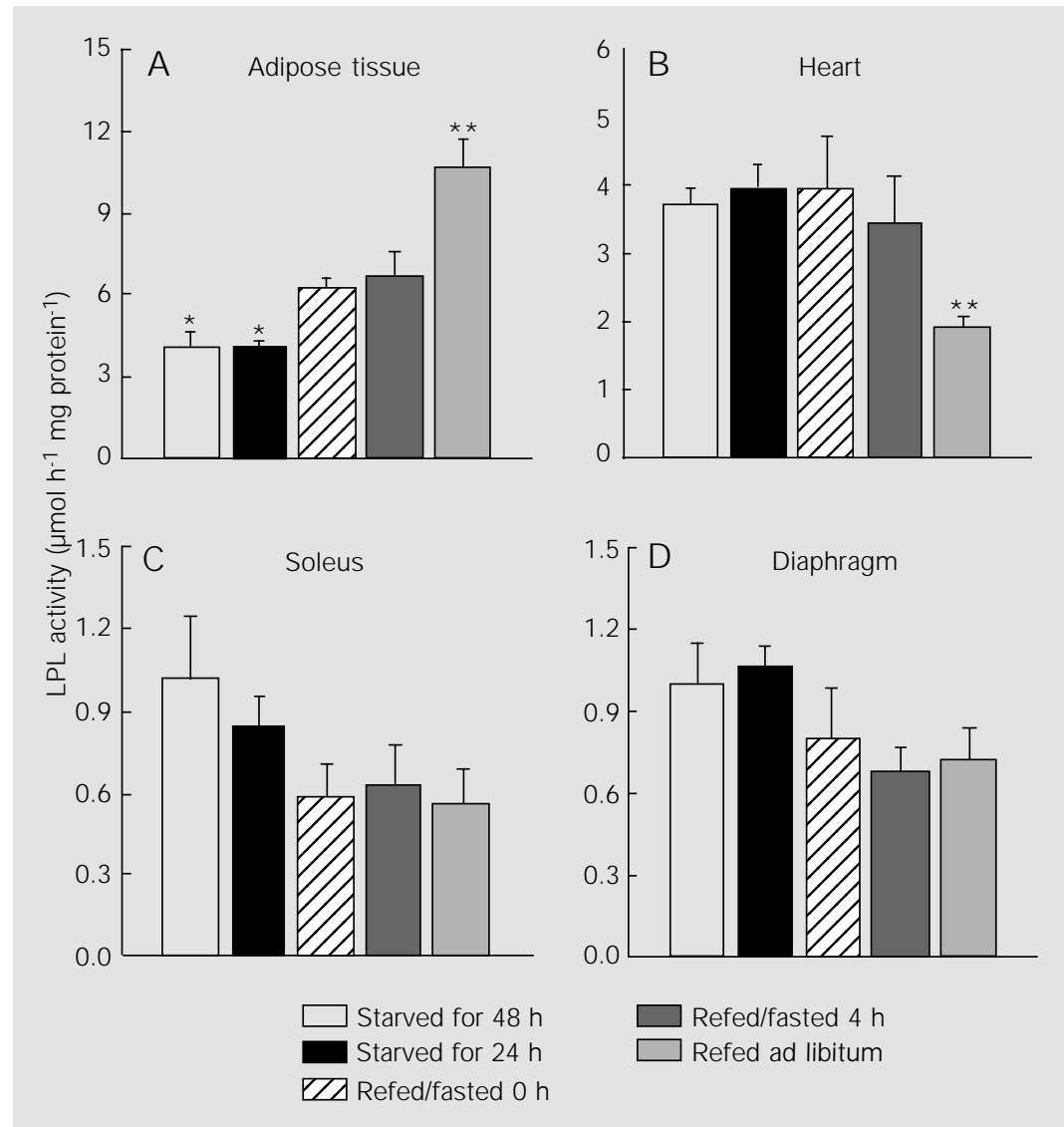

Figure 1. Lipoprotein lipase (LPL) activities in epididymal adipose tissue (A) and in heart (B), soleus (C) and diaphragm (D) muscles during progressive starvation and refeeding after 24$\mathrm{h}$ starvation. Tissue LPL activities (mean $\pm \mathrm{SEM}$ ) were measured in homogenates obtained from Wistar rats starved for $48 \mathrm{~h}(\mathrm{~N}=6)$, starved for $24 \mathrm{~h}(\mathrm{~N}=10)$, refed/fasted $0 \mathrm{~h}(\mathrm{~N}=6)$, refed/fasted $4 \mathrm{~h}(\mathrm{~N}=6)$, and refed ad libitum $(\mathrm{N}=10)$. $* \mathrm{P}<0.05$ for starved vs refed groups; $* * \mathrm{P}<0.05$ vs other groups (unpaired Student t-test).

sue LPL activity after $24 \mathrm{~h}$ of starvation and the partial restoration of enzyme activity within $2 \mathrm{~h}$ of refeeding occurred concomitantly with unchanged cardiac LPL activity a few hours after refeeding. Therefore, during this period, the activities in adipose tissue and heart are comparable and cardiac muscle LPL may contribute significantly to TAG clearance during the first few hours of refeeding following $24 \mathrm{~h}$ of starvation. 


\section{References}

1. Karpe F, Olivecrona T, Olivecrona G, Samra J S, Summers LKM, Humphreys SM \& Frayn KN (1998). Lipoprotein lipase transport in plasma: role of muscle and adipose tissue in regulation of plasma lipoprotein lipase concentrations. J ournal of Lipid Research, 39: 2387-2393.

2. Borenstajn J \& Robinson DS (1970). The effect of fasting on the utilization of chylomicron triglyceride fatty acids in relation to clearing factor lipase (lipoprotein lipase) releasable by heparin in the perfused heart. J ournal of Lipid Research, 11: 111117.

3. Doolitle MH, Ben-Zeev O, Elovson J , Martin D \& Kirchgessner TG (1990). The response of lipoprotein lipase to feeding and fasting. Evidence for posttranslational regulation. J oumal of Biological Chemistry, 265: 4570-4577.

4. Cryer A, Riley SE, Williams ER \& Robinson DS (1976). Effect of nutritional status on rat adipose tissue, muscle and posthepain plasma clearing factor lipase activities: their relationship to triglyceride fatty acid uptake by fat-cells and to plasma insulin concentrations. Clinical Science and Molecular Medicine, 50: 213-221.

5. LaDu MJ , Kapsas H \& Palmer WK (1991). Regulation of lipoprotein lipase in adipose tissue and muscle tissues during fasting. American J ournal of Physiology, 260: R953-R959.

6. Benavides $A$, Siches $M \&$ Llobera $M$
(1998). Circadian rhythms of lipoprotein lipase and hepatic lipase activities in intermediate metabolism of adult rat. American J ournal of Physiology, 275: R811R817.

7. Bergö $M$, Olivecrona $G \&$ Olivecrona $T$ (1996). Forms of lipoprotein lipase in rat tissues: in adipose tissue the proportion of inactive lipase increases on fasting. Biochemical J ournal, 313: 893-898.

8. Sugden MC, Holness MJ \& Howard RM (1993). Changes in lipoprotein lipase activities in adipose tissue, heart and skeletal muscle during continuous or interrupted feeding. Biochemical J ournal, 292: 113-119.

9. Lee JJ, Smith PJ \& Fried SK (1998). Mechanisms of decreased lipoprotein lipase activity in adipocytes of starved rats depend on duration of starvation. J ournal of Nutrition, 128: 940-946.

10. Bonnet $M$, Leroux $C$, Faulconnier $Y$, Hocquette J F, Bocquier F, Martin P \& Chilliard $Y$ (2000). Lipoprotein lipase activity and mRNA are up-regulated by refeeding in adipose tissue and cardiac muscle of sheep. J oumal of Nutrition, 130: 749-756.

11. Enerback S, Semb H, Tavemier ] , Bjursell G \& Olivecrona T (1988). Tissue-specific regulation of guinea-pig lipoprotein lipase; effects of nutritional state and of tumor necrosis factor on mRNA levels in adipose tissue, heart and liver. Gene, 64: 97106.
12. Hietanen E \& Greenwood MRC (1977). A comparison of lipoprotein lipase activity and adipose tissue differentiation in growing male rats. J ournal of Lipid Research, 18: $480-490$.

13. Nilsson-Ehle $P \&$ Schotz MC (1976). A stable, radioactive substrate emulsion for assay of lipoprotein lipase. J ournal of Lipid Research, 17: 536-541.

14. Belfrage P \& Vaughan M (1969). Simple liquid-liquid partition system for isolation of labeled oleic acid mixtures with glycerides. J oumal of Lipid Research, 10: 341344.

15. Lowry $\mathrm{OH}$, Rosebrough NJ, Farr AL \& Randall RJ (1951). Protein measurement with the Folin phenol reagent. J oumal of Biological Chemistry, 193: 265-275.

16. Ruge $T$, Bergö $M$, Hultin $M$, Olivecrona $G$ \& Olivecrona T (2000). Nutritional regulation of binding sites for lipoprotein lipase in rat heart. American J oumal of Physiology, 278: E211-E218.

17. Pedersen ME, Wolf LE \& Schotz MC (1970). Hormonal mediation of heart lipoprotein lipase activity after fat feeding. Biochimica et Biophysica Acta, 666: 191197.

18. Boivin A, Montplasier I \& Deshaies $Y$ (1994). Postprandial modulation of lipoprotein lipase in rats with insulin resistance. American J ournal of Physiology, 267: E620-E627. 